\title{
Integrating molecular identification of pelagic eggs with geostatistical mapping to improve the delineation of North Sea fish spawning grounds
}

\author{
Stéphanie Lelièvre ${ }^{1}$, Marc Jérôme ${ }^{2}$, Grégory E. Maes ${ }^{3}$, Sandrine Vaz ${ }^{1}$, \\ Sachidhanandam Calaivany ${ }^{2}$, Véronique Verrez-Bagnis ${ }^{2, *}$ \\ ${ }^{1}$ Fisheries Resources Laboratory, Ifremer, Boulogne sur Mer, France \\ ${ }^{2}$ Biotechnology and Marine Resources Unit, Ifremer, Nantes, France \\ ${ }^{3}$ Fish Genetics Group, Laboratory of Biodiversity and Evolutionary Genomics, \\ Katholieke Universiteit Leuven, Leuven, Belgium
}

\begin{abstract}
Maps of the spawning grounds of commercially important fishes are necessary when assessing the level of connectivity between life stages of fishes and for identifying ecologically valuable marine areas. A first step toward mapping the spawning grounds is a reliable and rapid species identification of pelagic fish eggs to assess the spatio-temporal distribution of spawning aggregations. As many species have similar egg sizes and morphology, the molecular validation of visually identified eggs is often essential for the use of such data in fisheries management. In the present study, we developed a rapid 16S rRNA PCR-restriction fragment length polymorphism (RFLP) assay to distinguish between formalin-fixed fish eggs of dab Limanda limanda, flounder Platichthys flesus and pout Trisopterus spp., which were collected during the 2008 International Bottom Trawl Survey in the Eastern English Channel and southern North Sea. A comparison of the rapid 16S rRNA PCR-RFLP method with initial visual identification revealed $93 \%$ of correct identifications for dab, $90 \%$ for pout, but only $64 \%$ for flounder, representing an overall error rate of $17 \%$. Visual misidentification occurred mainly between dab and flounder and between flounder and pout. Egg abundance and the relative proportions of each species were subsequently analysed geostatistically. Molecular identifications were incorporated to obtain corrected interpolated distribution maps, taking into account the results from molecular identifications as a correction factor. This highlighted the distinct spawning grounds for the 3 studied taxa and facilitated the identification of regions of high conservation value for these species.
\end{abstract}

KEY WORDS: Fish eggs · PCR-RFLP · 16S rRNA · Geostatistical analyses · Distribution · Spawning grounds

\section{INTRODUCTION}

Synergy between environmental changes and increasing anthropogenic pressure has led to a dramatic decline in biodiversity in the world's oceans and coastal areas. The obvious over-exploitation of several fish stocks has prompted authorities to take urgent measures to safeguard species biodiversity and to improve management of marine habitats. A global strategy, advocated by the scientific community, is the instigation of ecosystem-based, sustainable sea use management (Jennings et al. 2001). Such an approach necessitates spatially explicit management decisions that focus on a specific ecosystem and the range of anthropogenic and natural factors affecting it. Marine protected areas (MPAs) have received great attention because of their potential benefits for the conservation of biodiversity and are 
increasingly being studied for the purpose of fishery management. In order to preserve the resilience of fish populations to natural or human disturbances and to promote their regeneration capacity, efficient MPA networks need to be designed to match the populations' larval dispersal patterns (Hilborn et al. 2004). Hence, a detailed knowledge of spawning aggregations (the goal of the present study) and larval transport rates may improve the spatial management of these species (Christensen et al. 2009).

The Dover Strait, a narrow corridor at the junction of the English Channel and the North Sea, is subject to heavy shipping traffic and fishing pressure. The local commercial fishery, mainly operated by France, the UK, Germany, The Netherlands and Belgium, benefits from a high species richness and fish abundance. It has resulted in serious overexploitation of stocks over the last decades (Daan 1997, Greenstreet et al. 1999, Kjærsgaard et al. 2009). Consequently, the exploitation of most major commercial species stocks in the North Sea is now mainly based on the first-year classes of the population. Yearly fluctuations in recruitment have a high impact on the demographic stability of harvested fish populations, and recruitment success is becoming a fundamental parameter for fisheries management. The dispersive egg and larval stages are critical phases in the fish life cycle, subjected to high mortality due to predation and unpredictable environmental conditions. As a result, spawning grounds are considered sensitive habitats, both in terms of ecosystem functioning and fishery activities. Hence, it is essential to identify, investigate and subsequently protect spawning grounds of high ecological value in order to improve the management of fish stocks and to maintain appropriate population levels. The reliable identification of early life stages is pivotal in monitoring spatio-temporal species composition, and thus in mapping the relative densities of egg/larval aggregations during a spawning season. This has unfortunately been impossible because of similarities in egg sizes and morphology. Thus, molecular validation of visually identified eggs is required to exploit such data in fisheries management.

Many fish species spawn during winter in the north-east Atlantic, including the gadids cod Gadus morhua, whiting Merlangius merlangus, 3 species of Trisopterus (T. luscus, T. minutus and T. esmarkii), and the flatfishes dab Limanda limanda and flounder Platichthys flesus.

Fish eggs are generally identified using morphological criteria under a binocular microscope. However, many eggs, such as those of dab and flounder, have the same size range. Early stages are therefore very difficult to identify visually (Taylor et al. 2002, Bayha et al. 2008). A number of molecular tools (mainly used for the identification of processed fish products) have often proven useful for the identification of fish (for a complete review, see e.g. Teletchea 2009, Puyet \& Bautista 2010, Rasmussen \& Morrissey 2011). These molecular tools allow for a rapid and reliable identification of all fish life history stages from eggs to adults (Karaiskou et al. 2007). While later life stages can be recognised easily under a microscope, molecular methods are particularly useful for the identification of fish eggs, where size and shape can greatly overlap at sampling.

The main problem regarding the genetic identification of fish eggs is the preservatives used for the fixation and conservation of egg samples. Many preservatives may be used, but to be visually identified, eggs are usually fixed and preserved in formaldehyde. As reported by many authors (Chang \& Loew 1994, Akimoto et al. 2002, Skage \& Schander 2007, Sawada et al. 2008), this method of fixation may cause fragmentation or alteration of the DNA, thus endangering DNA analysis. Moreover, the duration of formalin fixation may also affect the quality of the extracted DNA, especially for pelagic eggs at the earliest developmental stages. This becomes clear in the studies of Akimoto et al. (2002), who only managed to amplify 6 out of 10 formalin-fixed pelagic eggs belonging to the genus Beryx on a shorter region of $125 \mathrm{bp}$ for the $16 \mathrm{~S}$ rRNA gene. Similarly, when Karaiskou et al. (2007) used a PCR-restriction fragment length polymorphism (RFLP) method based on a $370 \mathrm{bp}$ fragment of cytochrome $b$ to identify the eggs of European horse mackerel species, they reported that egg identification was more successful for ethanol-preserved eggs compared to formalinpreserved eggs. However, Perez et al. (2005) demonstrated the possibility of DNA extraction with formalin-fixed hake Merluccius merluccius and megrim (Lepidorhombus whiffiagonis and L. boscii) eggs.

Sezaki et al. (2001) successfully identified formalinfixed chub mackerel Scomber japonicus and spotted mackerel Scomberomorus munroi eggs based on a $320 \mathrm{bp}$ region of the cytochrome $b$ gene and using a PCR-RFLP approach. A PCR-RFLP method on a cytochrome $b$ fragment gene was also recently specifically developed for formalin-fixed eggs to distinguish cod, haddock and whiting, while comparing results with visual identification (Lelièvre et al. 2010). In the latter study, eggs were formalin-fixed in a $<1 \%$ formalin buffer and stored after 2 to $3 \mathrm{wk}$ of fix- 
ation in a storage buffer without formalin to perform further DNA-based analysis. In the present study, we chose to preserve fish eggs using the fixation and storage buffers as in Lelièvre et al. (2010) to visually pre-sort eggs before performing DNA-based egg species identification. We initially focused on the reliable identification of formalin-fixed eggs of dab, flounder and a group of 3 Trisopterus species (hereinafter reforced to as 'pout') whose eggs are very similar and difficult to distinguish visually. We first designed a PCR-RFLP assay based on a $16 \mathrm{~S}$ rRNA gene region to identify a representative subsample of the species' eggs. After evaluating the species identification success for both the visual and the molecular methodology, we then used the inferred relative proportion of each species to perform geostatistical analyses to obtain accurate interpolated maps of spawning grounds. Maps based solely on molecular data were used to improve the accuracy of the maps obtained by visual identification and to enable a final comparison of spawning habitats using all collected samples.

\section{MATERIALS AND METHODS}

\section{Data collection and sampling}

The present study was based on data collected in 2008 during the International Bottom Trawl Survey (IBTS) organised by the International Council for the Exploration of the Sea (ICES) (Fig. 1). Ifremer participates each year in the IBTS sea survey during the first quarter (January to February) in the southern part of the North Sea. The goal of this survey was to estimate the abundance and recruitment level of the main fish species commercially exploited in the North Sea. During this survey, muscle tissue of adult fishes of the target species for this study was also collected in the southern part of the North sea during the IBTS sea survey (stored in $70 \%$ ethanol) from bottom trawl samples to obtain standard references with reliable identification and to assess the likelihood of those specific species spawning in the surveyed region.

Fish egg samples were collected using a Continuous Underway Fish Egg Sampler (CUFES; Checkley et al. 1997, 2000, Zwolinski et al. 2006), a sampling method proven to be efficient in the North Sea during winter (Lelièvre et al. in press). During sampling, water was pumped continuously from $5 \mathrm{~m}$ below the surface and filtered over a mesh size of $500 \mu \mathrm{m}$. Samples were collected every $30 \mathrm{~min}$. For each sample,

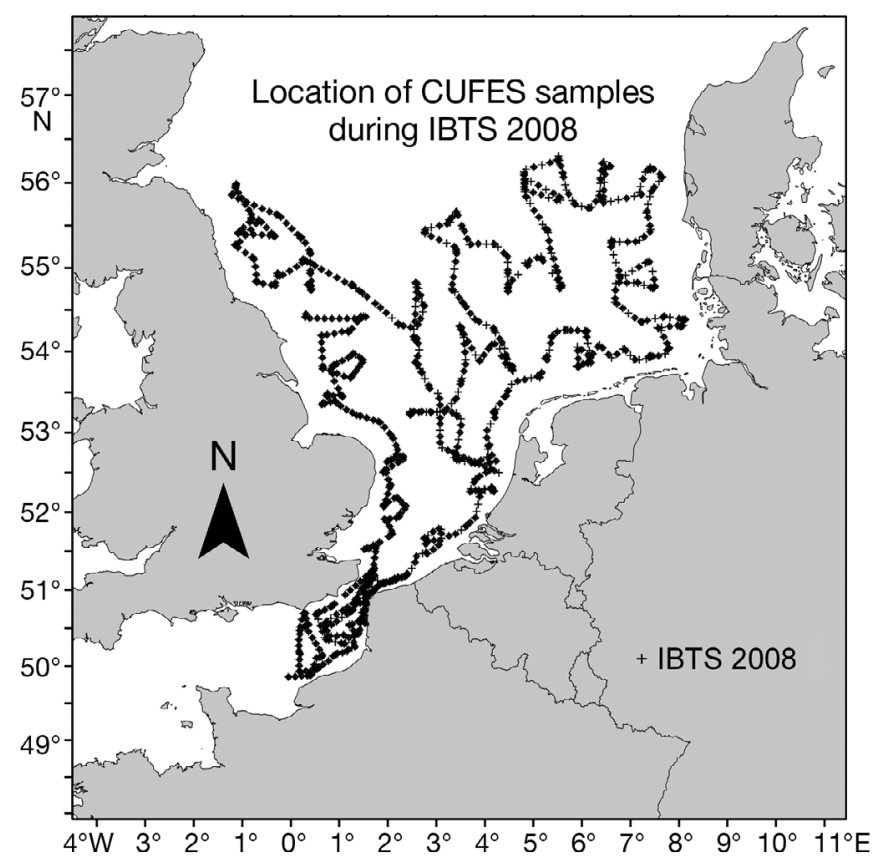

Fig. 1. Location of the Continuous Underway Fish Egg Sampler (CUFES) samples during the International Bottom Trawl Survey (IBTS) 2008

the volume of filtered water was determined using both sample duration and pump flow. Samples were fixed in a $0.9 \%$ buffered formalin seawater solution and transferred to a storage solution without formalin after 2 to 3 wk of fixation (see Lelièvre et al. 2010 for details). A spatially representative subset of 38 samples was selected for molecular identification and validation. Where there were too many eggs per sample, a maximum of 10 were selected for analysis.

\section{Microscopic identification of fish eggs}

Fish eggs were identified at the species level under a binocular microscope. The microscopic identification was based on variables such as size, the presence of oil globules and the degree of pigmentation (Russell 1976, Munk \& Nielsen 2005). The absence of sexually mature adults of a given species in neighbouring trawl hauls helped rule out specific species during the taxonomic identification of eggs in the CUFES samples. If a species was not present in the nearby trawls, the presence of this species' eggs was considered unlikely. Different developmental stages could be identified. Corresponding to Stages IA and IB, there was no embryo at Stage 1. At Stage 2, which corresponds to Stages II and III, an early embryonic development could be observed. At Stage 3, which 
corresponds to Stages IV and V, a well-developed embryo could be found, as described by Thompson \& Riley (1981). Only Stage 1 eggs were used in the present study as, being recently laid, they were more likely to be in the vicinity of the spawning grounds, thus enabling a more reliable location of spawning grounds.

In a previous study (Lelièvre et al. 2010), we grouped the different sampled eggs into 3 groups, based on morphological traits, given that many species spawning in the Eastern English Channel and the southern North Sea exhibit the same egg size range during the studied period. Misidentification of the egg species was not possible between groups but very likely within each group: Group 1 included eggs of 3 rockling species (Ciliata mustela, C. septentrionalis and Enchelyopus cimbrius), and Group 2 included eggs of other Gadidae species such as cod, haddock and whiting, which were the subject of a previous study (Lelièvre et al. 2010). Group 3, including dab, flounder and pout (Table 1), is the topic of this paper.

Overall, 1050 station samples originating from all sampled stations (with approximately 52000 dab and 4107 flounder eggs at Stage 1 and 212 pout eggs at later stages) were identified by binocular microscope during the 2008 IBTS sea survey. A subset of 353 eggs originating from 38 samples was analysed genetically after visual identification. We initially labelled 226 eggs as Limanda limanda, 64 eggs as Platichthys flesus and 63 eggs as Trisopterus spp.

\section{DNA extraction and amplification}

DNA from adult fish muscle tissue was initially extracted using a modified phenol/chloroform/isoamyl alcohol extraction method (Jérôme et al. 2003). However, when applied to fish eggs, the resulting low yield of this extraction method required the use of a second method based on magnetic bead technology (ChargesSwitch ${ }^{\circledR}$ Forensic DNA Purification Kit, Invitrogen). Eggs were labelled after microscope identification, and total DNA was extracted from individual egg tissue as described by Lelièvre et al. (2010).

The 16S rRNA gene fragment from each species was amplified using 2 primers 16S-F (5'-CAA GCA GAG AAG ACC CTA TGG) (C. Lemaire unpublished) and 16S-R-univ (5'-GGT AAC TCG GTT CGT TGA TCG G), specifically designed for this study. The PCR reactions were carried out in a total volume of $50 \mu \mathrm{l}$, including a $1.25 \mu \mathrm{l}$ DNA template, $0.2 \mathrm{mM}$ dNTP (Interchim), 2 mM MgCl $2,10 \mu \mathrm{l} 5 \times$ buffer, 1.25 units of GoTaq ${ }^{\circledR}$ polymerase (Promega) and $0.2 \mathrm{mM}$ of each primer; molecular biology grade water (Interchim) was added to adjust to the final volume. PCR was performed in a MyCycler ${ }^{\mathrm{TM}}$ thermocycler (Biorad). The PCR cycle consisted of a 5 min preheating step at $95^{\circ} \mathrm{C}, 35$ cycles of amplification $\left(95^{\circ} \mathrm{C}\right.$ for $30 \mathrm{~s}$, $48^{\circ} \mathrm{C}$ for $30 \mathrm{~s}, 72^{\circ} \mathrm{C}$ for $40 \mathrm{~s}$ ) and a final 7 min extension at $72^{\circ} \mathrm{C}$.

The DNA amplification was checked on a $1.5 \%$ agarose gel (Interchim) using TAE buffer (2 mM EDTA, $40 \mathrm{mM}$ Tris acetate, $\mathrm{pH}$ 8.5). Band visualisation was carried out using GelRed ${ }^{\mathrm{TM}}$ (Interchim) via ultraviolet trans-illumination (Image Master VDSCL, GE Healthcare) and 1D Elite software (GE Healthcare). The size of the expected PCR products was estimated using the MassRuler ${ }^{\mathrm{TM}} 100 \mathrm{bp}$ DNA ladder range (MBI Fermentas).

\section{DNA sequencing of reference adult DNA}

Before sequencing, double-stranded PCR products were purified by a simple bind-wash-elute procedure on a silica membrane (QIAquick PCR Purification Kit, Qiagen) according to the manufacturer's protocol. PCR fragments were used for direct cycle sequencing with the dye terminator cycle sequencing kit (Beckman) following the manufacturer's protocol. A Beckman Coulter CEQ 8000 DNA sequencer was used for sequencing analysis in both directions with the primers used for PCR amplification. The DNA sequences were edited with BioEdit software (Hall 1999). The same primers and amplification conditions were used for all fish eggs before RFLP analysis.

\section{RFLP of the 16S rRNA gene fragment}

Restriction maps of a total of 40 16S rRNA gene sequences (31 sequences retrieved from GenBank 
and new sequences obtained from 2 individuals per species, except for Trisopterus esmarkii, for which only 1 individual was sampled in this study) were generated using the FastPCR software (Kalendar et al. 2009). The AciI restriction enzyme (whose recognition site is $5^{\prime} \mathrm{C} / \mathrm{CGC}$ ) was selected, based on its ability to generate characteristic restriction profiles for each species with band sizes easily distinguishable on agarose gels. Restriction was carried out at $37^{\circ} \mathrm{C}$ for $4 \mathrm{~h}$ with a $20 \mu \mathrm{l}$ reaction mixture containing $10 \mu \mathrm{l}$ of PCR products and 2 units of the Aci enzyme in the buffer recommended by the manufacturer (Ozyme). The reaction was stopped by heating at $65^{\circ} \mathrm{C}$ for $20 \mathrm{~min}$. The DNA restriction fragments were separated using electrophoresis at $90 \mathrm{~V}$ for $50 \mathrm{~min}$, on $3 \%$ agarose gels as described above. DNA fragments with sizes below 50 bp generated in the restriction digestion were not used for the identification because they could not be reliably scored.

\section{Geostatistical analyses and interpolated maps}

Many fish populations exhibit particular distribution and aggregation patterns at different times of the year as well as in different phases of their life cycle (Mello \& Rose 2005, Vaz et al. 2005). Geostatistics, which represent a suite of methods for analysing spatial data, were used to identify and quantitatively describe the spatial distribution of each species' eggs (Webster \& Oliver 2001). Geostatistics can also be applied to the estimation of values of variables of interest at non-sampled locations from more or less sparse sample data points based on spatial autocorrelation between these points. Geostatistical estimation is known by the general term 'kriging'.

In order to enable distance calculation from angular coordinates, the longitude correction (longitude $\times \cos$ [(latitude $\times \pi) / 180]$ ) was used to transform decimal degrees of longitude into decimal degrees of latitude, which are of constant distance.

Geostatistics do not require full normality, but perform better if the distribution approaches normality as much as possible. Egg abundance data were tested for normality using histograms, skewness and kurtosis. The data were transformed when the skewness value exceeded $|1|$ and/or kurtosis exceeded 1 and when a normalising function improving the data distribution was found. As a result, egg abundances were $\log$ transformed $(\log 10[x+1]$, with $x$ being the abundance) to reduce data skewness.

The variogram, the central tool of geostatistics, is a function that measures the relation between pairs of observations, which may be any distance apart. It is a model of the spatial auto-correlation pattern of the variable of interest that summarises how the variance of a variable changes as the distance and direction separating any 2 points varies. Therefore, the variogram is a plot of the mean variance of each pair of points against their separation distance, often referred to as the experimental variogram. Typically, variance increases with the separation distance between the observations until it reaches a maximum called 'sill variance' which corresponds to the maximum variance of the data. The lag distance at which the sill is reached (the range) marks the limit of spatial dependence and indicates the average diameter of patches (Webster \& Oliver 2001). The variogram has a positive intercept on the ordinate axis, called 'nugget variance', which is the amount of variance not explained by the spatial model and which mostly arises from variation occurring over distance smaller than the sampling interval. An experimental variogram was computed for each fish species and for both visual and molecular identification data. These experimental variograms were fitted by non-linear models.

Four variogram models (exponential, circular, spherical and pentaspherical) were visually and statistically adjusted to the experimental variogram using least-square regression. The model with the best visual and statistical fit with the experimental variogram was retained as the theoretical variogram and was used to estimate the nugget, sill and range parameters that characterise the shape of the variogram. The model retained may therefore differ for each dataset.

Local trend or drift violates some basic assumptions of geostatistics because the values change in a smooth and predictable way. Variables were examined for trend at the outset by fitting a low-order polynomial (linear or quadratic regression) on the spatial coordinates (Webster \& Oliver 2001). When the fitted function accounted for over $20 \%$ of the variance, the variogram was computed using the abundance data residuals and compared to the variogram of the original data.

Furthermore, the amount of spatial structuring (Q) explained by the variogram was estimated as the variance attributable to spatial dependence (C) divided by the sill variance (i.e. the maximum variance in the data calculated as the sum $\left[\mathrm{C}+\mathrm{C}_{0}\right], \mathrm{C}_{0}$ being the nugget variance). High values of $\mathrm{Q}$ (up to a maximum of 1) indicated that the variable distribution was strongly structured in space. Finally, the estimated nugget, sill and range parameters were used to interpolate egg abundances on the mesh of a 
regular grid by using interpolation methods known as ordinary kriging or universal kriging in the case of a spatial drift.

Geostatistical analyses were performed using GenStat v 7.1. The resulting interpolated values were imported into a geographical information system using the ArcMap 9.1 (ESRI) software. The program was used to produce continuous grids of 0.008 decimal degree resolution, displaying the spatial patterns of each variable. Extrapolated areas (located outside the study area) were discarded from the maps.

Egg abundance was transformed into its original units to enable the computation of the total egg abundance maps. The total abundance maps were multiplied with molecular maps to have final corrected maps for each species. The resulting maps were then log transformed again for mapping purposes. This approach has already been successfully used for cod, haddock and whiting (Lelièvre et al. 2010).

\section{RESULTS}

\section{PCR-RFLP analysis}

The amplification of the 16S rRNA gene produced a fragment of $254 \mathrm{bp}$ for dab and flounder and a fragment of $238 \mathrm{bp}$ for pout due to a 16 nucleotide deletion. Sequence analysis of 9 sequences obtained from this study from reference samples (2 adult specimens per species except for Trisopterus esmarkii; data not shown) combined with 31 sequences retrieved from GenBank (11 dab sequences, 14 flounder sequences and 6 pout sequences) indicated that this fragment was polymorphic enough to discriminate between dab, flounder and pout after digestion with only the AciI enzyme. The DNA fragments generated after the digestion $(114,81$ and $59 \mathrm{bp}$ for dab, 173 and $81 \mathrm{bp}$ for flounder and 126 and $112 \mathrm{bp}$ for pout) were compatible with the expected size on the basis of the restriction map (Fig. 2). The 3 pout species could not be distinguished with AciI on the studied 16S rRNA gene fragment, as they all displayed the same restriction profile with this enzyme, except for 3 Trisopterus minutus GenBank sequences (individuals sampled in the Mediterranean). Since in terms of abundance and commercial interest the 3 pout species are less important commercially than dab and flounder, we focused on the distinction of dab, flounder and the whole Trisopterus genus.

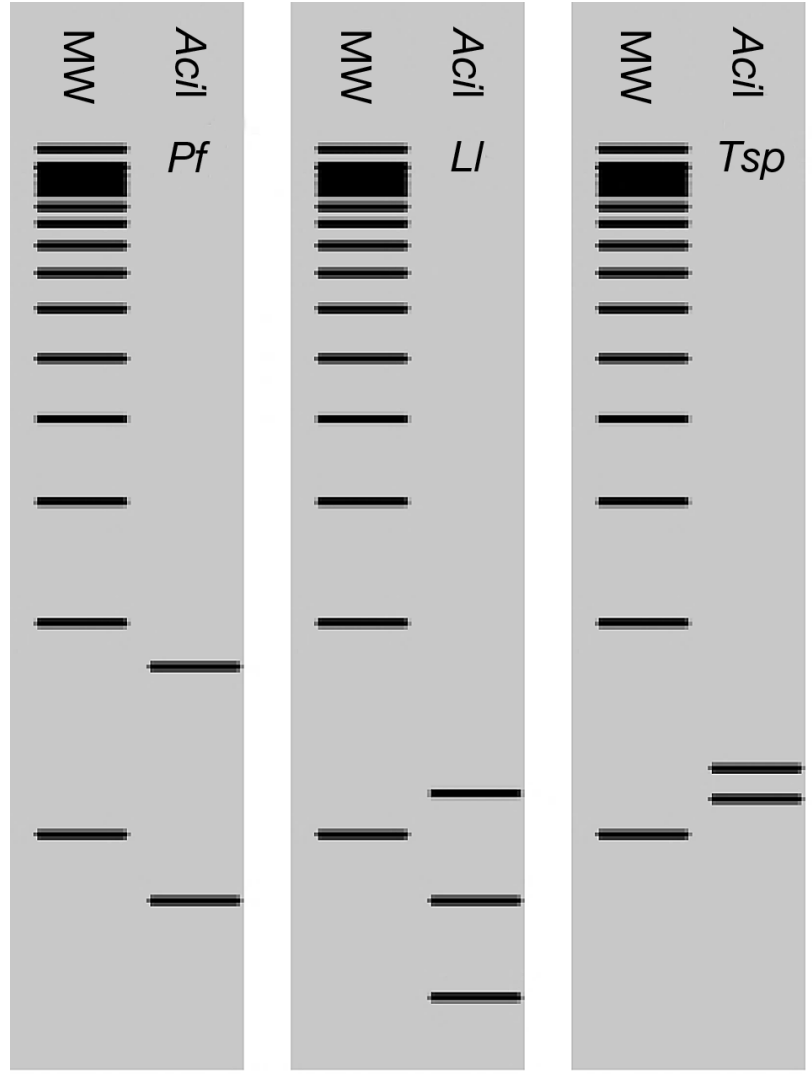

Fig. 2. Limanda limanda (Ll), Platichthys flesus (Pf) and Trisopterus spp. (Tsp). Synthetic 3\% agarose gel electrophoregram of DNA fragments after digestion by the AciI restriction enzyme. MW: $100 \mathrm{bp}$ standard molecular weight

\section{Molecular analyses validation}

Among the 353 eggs extracted, 164 were successfully amplified (46\%). Ten (out of 38 ) sites from the study area were not analysed due to a low DNA yield or a lack of amplification from egg extracts. All stations analysed were spread evenly across the study area, with the exception of the Belgian coast where no samples of sufficient quality could be analysed. In total, we discovered 28 visual identification errors out of the 164 eggs analysed (17\%), spread across 11 sites (39\% of the analysed stations; Fig. 3 ). Of the 107 eggs visually identified as dab based on morphological criteria, 99 eggs were confirmed as dab by molecular analyses $(92.5 \%$ correct identification, Table 2). Of the 47 visually identified flounder eggs, 30 were correctly identified by molecular analyses, while 5 were in fact pout and 12 were dab eggs (only $64 \%$ correctly identified). Of the 10 pout eggs analysed by molecular analyses, 7 were correctly identified visually, and 3 were in fact flounder eggs ( $70 \%$ correct identification). These results revealed 


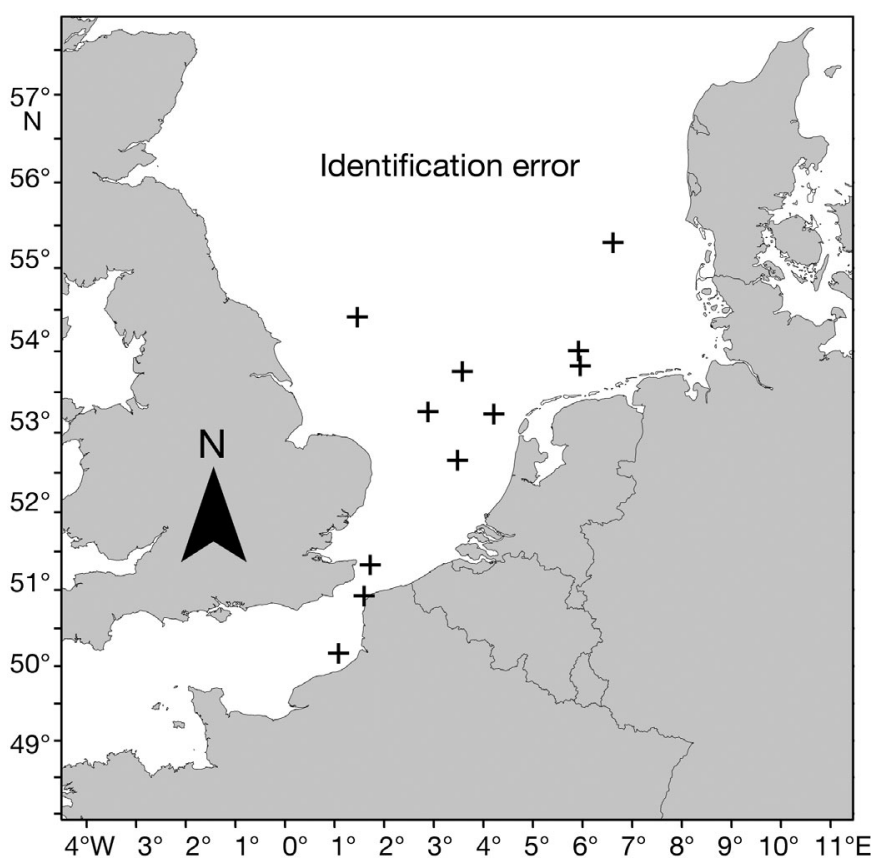

Fig. 3. Limanda limanda, Platichthys flesus and Trisopterus spp. Localisation of global error identification for all species of the group studied

that visual identification of eggs from flounder, and possibly pout, may be problematic and effectively require validation by molecular technique.

The relative error ratio per station was analysed for each species. It confirmed a good visual identification for dab and pout with a mean error of 0.04 and a median of 0 . For the latter species, however, these results should be regarded with caution because of the low number of eggs analysed. Flounder presented a higher error rate, with a mean of 0.37 and a median of 0.29 . Most of the time, errors in flounder identification were due to the confusion with dab $(71 \%)$, compared to a $29 \%$ confusion with pout. However, there was no confusion between dab and pout.

Table 2. Limanda limanda, Platichthys flesus and Trisopterus spp. Absolute and proportionally correct identification

\begin{tabular}{|llrrrrr|}
\hline $\begin{array}{l}\text { Microscope } \\
\text { identification }\end{array}$ & Dab & Flounder & $\begin{array}{l}\text { Pout } \\
\text { spp. }\end{array}$ & $\begin{array}{c}\text { Micro- } \\
\text { scope } \\
\text { sum }\end{array}$ & $\begin{array}{c}\text { \% of } \\
\text { correct } \\
\text { identi- } \\
\text { fication }\end{array}$ \\
\hline Dab & 99 & 8 & 0 & 107 & 92.5 \\
Flounder & 12 & 30 & 5 & 47 & 63.8 \\
Pout spp. & 0 & 3 & 7 & 10 & 70 \\
Molecular & 111 & 41 & 12 & 164 & \\
sum & & & & & \\
\hline
\end{tabular}

\section{Interpolated map}

Geostatistical analyses were applied to both egg abundance data (for each species identified morphologically using all available samples, i.e. 1050 observations) and relative egg abundance data (for each species identified genetically in each sample using a subset of 28 successfully analysed observations; Table 3). Generally, the extent of the spatial structure (range) was comparable for each species based on visually identified data (about $1^{\circ}$, i.e. approximately $115 \mathrm{~km})$. However, the molecular data revealed a much more structured spatial distribution (larger Q values) and more variable patch extents (from $0.6^{\circ}$ for flounder to $1.7^{\circ}$ for pout; Fig. 4). The relative occurrence maps (Fig. 5) of each species were multiplied with abundance maps of the considered group. These were obtained by visual identification in order to produce distribution maps of the spawning grounds for each species in the entire studied area (Fig. 6).

Although the studied species were found to occur in a large proportion of the study area, molecular analyses revealed that dab, flounder and the pout species seemed to have more distinct spawning grounds. Corrected maps (Fig. 6) showed that dab spawned to a large extent mainly in the centre and offshore parts of the study area, whereas flounder seemed to prefer more coastal areas near the French, Belgian and Dutch coasts. The distribution of pout was unclear because of the very low sample size, indicating a lack of large spawning aggregations at the time of sampling. Still, an aggregation of pout eggs was observed near the Belgian coast and another was observed on the Dogger Bank. However, due to the lack of appropriate samples along the Belgian coast, the distribution patterns in this area are based on interpolation from adjacent areas and probably need verification. Corrected maps were very similar to maps from visual data (not shown), confirming the relatively reliable identification by microscope. Generally, however, molecularly corrected maps showed that fish egg distribution was much more restricted than visual data maps had illustrated. They revealed that the distribution of each species' spawning grounds was much more spatially restricted than initially expected.

\section{DISCUSSION}

The detailed mapping of breeding grounds for exploited fish species is a prerequisite for sustainable management practices and for the pro- 
Table 3. Limanda limanda, Platichthys flesus and Trisopterus spp. Geostatistical analyses on visual and molecular data for each species. Trend fit: variation explained by the quadratic trend and removed before variographic analysis; model: variogram model retained; Q: amount of spatial structuring explained by the variogram; nugget: amount of variance not explained by the spatial model; sill: maximum variance of the data; range: approximate average diameter of patches in decimal degrees of latitude

\begin{tabular}{|c|c|c|c|c|c|c|c|}
\hline Species & Transformation & Trend fit (\%) & Model & Q (\%) & Nugget & Sill & Range ( ${ }^{\circ}$ lat) \\
\hline \multicolumn{8}{|c|}{ Visual identification data $(n=1050)$} \\
\hline Dab & $\log _{10}(x+1)$ & 51.4 & Pentaspherical & 87.2 & 0.076 & 0.518 & 1.251 \\
\hline Flounder & $\log _{10}(x+1)$ & 19.6 & Pentaspherical & 60.7 & 0.096 & 0.148 & 1.013 \\
\hline Pout spp. & $\log _{10}(x+1)$ & 0.2 & Circular & 45.5 & 0.012 & 0.010 & 1.099 \\
\hline \multicolumn{8}{|c|}{ Molecular identification data $(n=28)$} \\
\hline Dab & None & 8.3 & Pentaspherical & 70.8 & 0.354 & 0.860 & 1.297 \\
\hline Flounder & None & 32 & Circular & 100.0 & 0.000 & 0.037 & 0.636 \\
\hline Pout spp. & None & 1.6 & Spherical & 89.7 & 0.013 & 0.113 & 1.701 \\
\hline
\end{tabular}

tection of ecologically important marine areas. The reliable assessment of species diversity within and connectivity patterns between spawning grounds requires fine-scale sampling efforts and powerful pelagic egg identification methodologies. Additionally, the integration of such data into geostatistical mapping analyses enables the identification of temporally stable spawning aggregations requiring protection and good management. The problem of visual fish egg identification can easily be solved through molecular techniques (but at a cost), resulting in high confidence about the timing and location of (over)

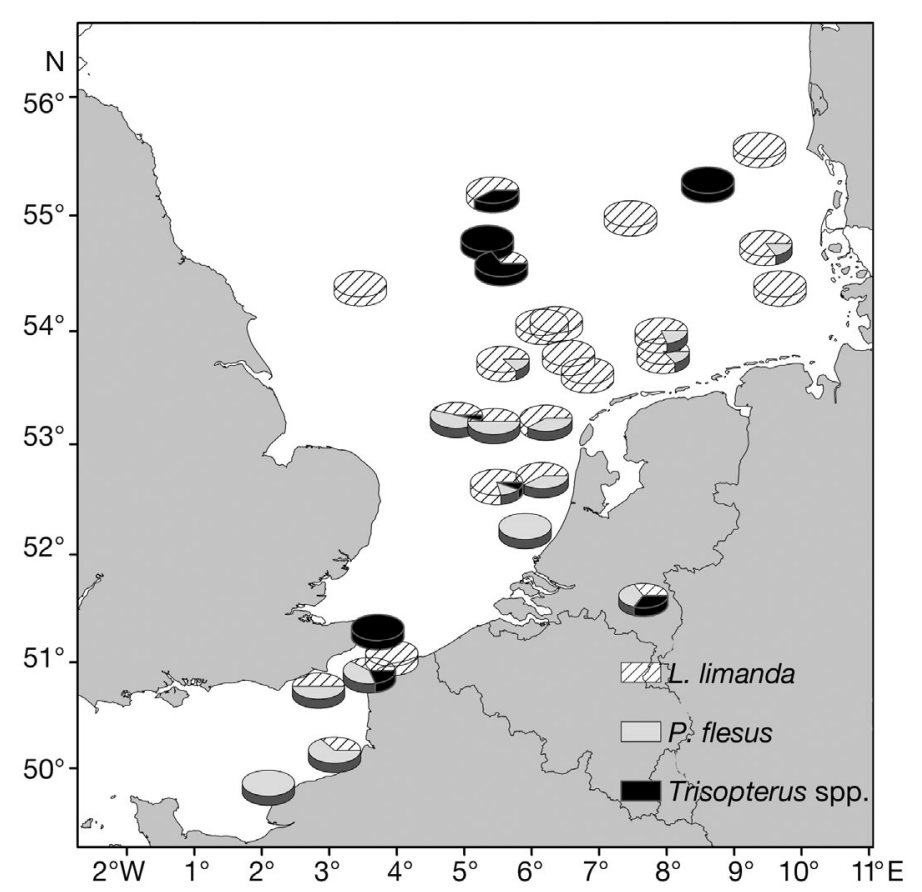

Fig. 4. Limanda limanda, Platichthys flesus and Trisopterus spp. Location of eggs identified by molecular analyses exploited fish species' spawning grounds. Our results demonstrate that only a subset of DNA-based egg identifications and validation is sufficient for analysing large sample sizes over a large geographical coverage, due to the easy integration of molecular data and geostatistical analysis.

\section{Molecular identification and technical issues in fish egg identification}

For formalin-fixed samples containing a low concentration of template DNA, mitochondrial DNA is often used in molecular analyses since it is more resistant to deterioration than nuclear DNA, due to its small size, circular structure and the protection offered by the cellular compartment of the mitochondrion. Moreover, nearly 100 mitochondrial genomes are present in eggs, each containing around 10 copies of the DNA (Hunter et al. 2010). The mitochondrial markers mostly used for species identification are the genes encoding cytochrome $b$ and 16S rRNA. Due to their high nucleotidic substitution rate enabling rapid identification, both markers have often been used for the differentiation of fish eggs (Aoyama et al. 2001, Karaiskou et al. 2007).

Identification based on RFLP is highly dependent on the distinctness and intensity of the PCR amplification products, the electrophoresis gels. The PCR must be optimised to lead to sufficiently discriminating restriction profiles after enzymatic digestion. In the present study, some difficulties were encountered during the amplification of fish egg DNA, and particularly first-stage (earlier egg without embryo) egg DNA. The variability of amplification yield between eggs could thus be mainly due to the low quantity of DNA in some eggs. Furthermore, the high 

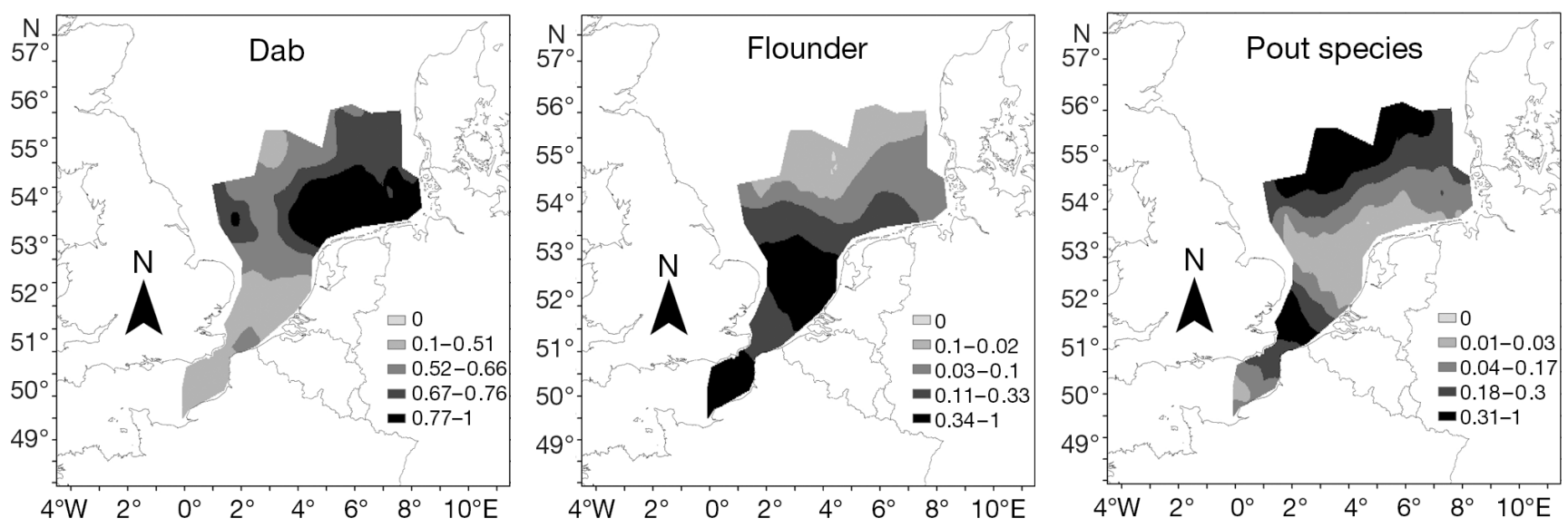

Fig. 5. Limanda limanda, Platichthys flesus and Trisopterus spp. Relative abundance distribution of pout eggs identified by molecular analyses. The maps represent the interpolated relative amount of eggs of each species found in each genetically analysed sample
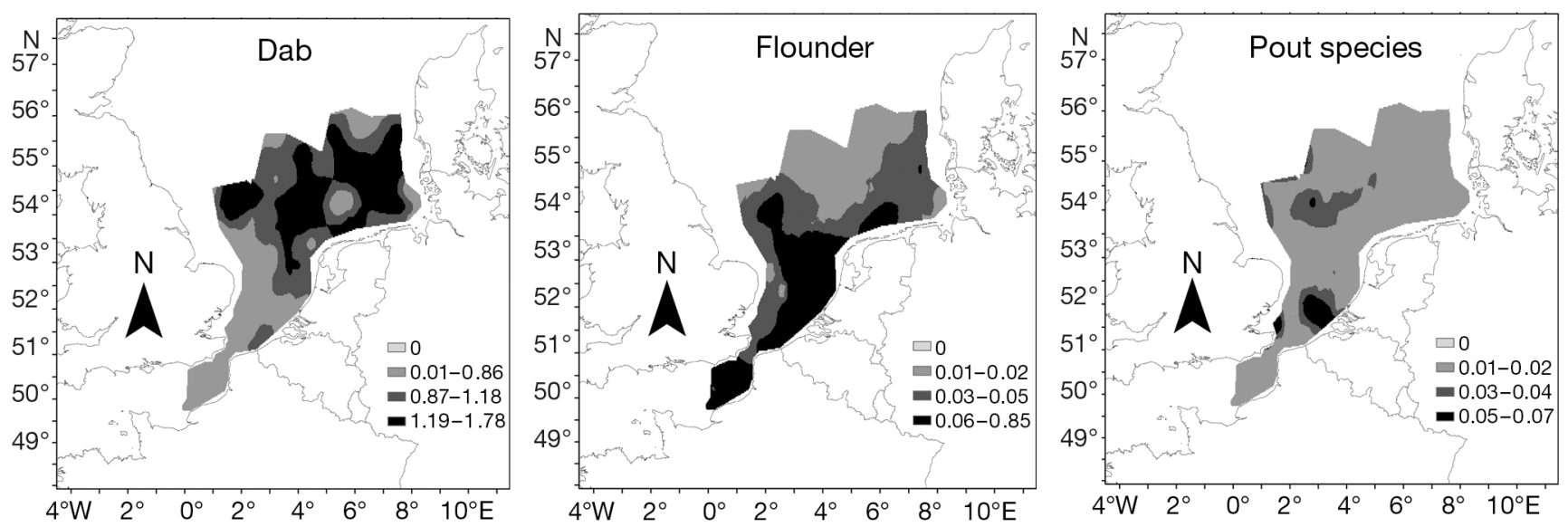

Fig. 6. Limanda limanda, Platichthys flesus and Trisopterus spp. Egg distribution corrected by molecular analyses. The scale represents the log-transformed egg densities per $20 \mathrm{~m}^{3}$

lipid content of fish eggs could reduce the DNA retrieval and increase residual substances after DNA extraction, which could inhibit PCR amplification (Aranishi et al. 2005). The use of buffered formalin, known to induce DNA fragmentation and nucleotide alterations, may explain the observed PCR yield variability (Chakraborty et al. 2006, Palmer 2009). However, in our study, eggs were only fixed in buffered formalin $(<1 \%)$ for 2 to $3 \mathrm{wk}$. The eggs were then stored in a conservation solution without formalin. This method of fixation and storage has already been successfully applied (Lelièvre et al. 2010). Overall, the observed identification errors were mainly due to egg size and spawning area overlapping between species. Therefore, the PCR-RFLP technique applied on the $16 \mathrm{~S}$ rRNA gene provided an accurate and reliable method for the identification of dab, flounder and pout eggs.

\section{Comparative mapping of the spawning grounds of dab, flounder and pout}

This study shows that dab and flounder exhibit 2 distinct spawning areas. Our results are concordant with earlier studies documenting the spawning grounds of dab by Van der Land (1991) and Rijnsdorp et al. (1992). Dab spawning occurs throughout the south-eastern North Sea, with offshore concentrations of eggs in the German Bight, north of the Frisian Islands, along the southern edge of the Dogger Bank and northeast of Flamborough Head (Harding \& Nichols 1987). These patterns were confirmed by our results and were also in agreement with data from Ehrenbaum (1905-1909) and Bohl (1957). It can be concluded that dab has a strong spawning site fidelity. Flounder spawn mainly inshore, near the Dutch coasts but also near the German and Danish 
coasts. Van der Land (1991) observed most flounder eggs in the area west and northwest of the Dutch west coast, the eastern English Channel and the area northwest of Helgoland, confirming that flounder has a well-defined spawning period and area. Following Quéro \& Vayne (1997), pout seem to be located inshore, in the English Channel but mainly near the French Atlantic coasts, between the Gironde Estuary and north of the Loire River, as well as along the Vendée coast. The southern distribution border of Trisopterus esmarkii lies around the Dogger Bank (Heessen et al. 2005). However, the low densities observed in our survey restrain us from drawing any conclusions on the distribution of pout spawning grounds. Overall, our results highlight the importance of the south-eastern part of the North Sea as the main spawning ground for the species investigated in this study as well as for many other species (Lelièvre et al. 2010).

\section{Reliable ichthyoplankton surveys}

Maps of fish spawning grounds can be based on various sources of information, including the occurrence of mature fish in trawl surveys (Hedger et al. 2004) and for some species acoustic records of calls made during courtship (Hawkins et al. 2002, Širovi et al. 2009). For pelagic spawners, plankton surveys provide another useful source of information (Checkley et al. 1997, Fox et al. 2008). Since eggs will diffuse away from spawning sites, it is desirable to identify the species at their earliest developmental stages. Ichthyoplankton surveys are a powerful tool for monitoring spawning areas when taxonomic identification is reliable enough (Fox et al. 2005). Recent advances in applying molecular genetics to plankton samples, including the present study, have largely overcome the problem of similar egg size and appearance between species (Fox et al. 2008, Goodsir et al. 2008, Lelièvre et al. 2010).

Given the cost involved in molecular analysis, such analyses should only be performed after a validation test on eggs with uncertain identification and on a subset of collected samples. Such an approach, ensuring that visual identification is fine-tuned and corrected with molecular results, ensures a cost effective and accurate use of these data.

To achieve the objective of international and European conservation of the marine environment, countries must implement a coherent network of MPAs in their territorial waters by 2012. In Canada, MPAs are considered to be an important tool for fisheries man- agement (Côté \& Finney 2006). Indeed, several studies have shown that MPAs can achieve the objectives of conservation and fisheries management by increasing biodiversity, restoring population structure and the dynamics of stocks and by facilitating the establishment of stable and productive ecosystems (Fisher \& Frank 2002, Gell \& Roberts 2003, Roberts et al. 2005, Kraus et al. 2009). The closure of Georges Bank (in 1994) was an example of a measure directed at protecting the yellowtail flounder Limanda ferruginea and other Gadidae species. This closure has resulted in an increase in cod biomass and has also affected other species such as scallops. The protection zone had a positive effect on the habitat and the productivity of the ecosystem by reducing mortality due to fishing. Indeed, after 4 yr of protection, in 1998 the scallop population had increased 14 -fold, and the biomass and size of individuals had also increased. The cod stock increased by $18 \%$, that of yellowtail flounder by $80 \%$ (but was not completely restored), and haddock was completely restored.

Some MPAs are designed to protect spawning areas where the main commercial species spawn. However, in the evaluation of areas for protection, it seems important to take into account not only the spawning grounds but also nursery areas and migration. Detailed knowledge of the aggregation and transport processes of larvae may therefore improve the design of MPAs (Christensen et al. 2009) for the ultimate benefit of the fishery industry.

Thus, knowledge on spawning grounds can directly contribute to the sustainable management of fisheries resources, and managers may decide to prohibit the use of a given area to protect spawning grounds in order to maintain productive fishery. Additionally, fisheries management can limit trawl mesh size to protect adults and to ensure they have the opportunity to reproduce at least once (Fuiman \& Werner 2002).

\section{CONCLUSION}

The various phases of a fish life cycle are distributed across different spatial structures and scales. Indeed, reproducing adults are encountered in specific and distinct areas that differ from the spatial distribution of eggs, larvae and juveniles, which are mainly found in nursery areas.

Spawning areas are essential and of special interest because they are considered a key habitat for a species' resilience to harvesting. Moreover, suitable spawning habitats will strongly affect recruitment success (Borja et al. 1998, 2008) and, consequently, 
the demographic stability of a population (Bellier et al. 2007). Hence, the location, quality and size of spawning grounds are essential factors influencing the spatial and temporal dynamics of fish populations. We have shown that the application of molecular analyses to fish eggs exponentially increases the accuracy of spawning maps and, ultimately, will enhance our understanding of the spatial dynamics of fish populations. Such knowledge is necessary to implement a spatially explicit, ecologically sound protection scheme. Indeed, the delineation and size of MPAs, which may be defined by the habitat needed for spawning or larval settlement, would require such information. The decision to close a given area or season to fishing in order to protect spawning and nursery grounds would have positive effects on the exploited populations and ultimately benefit the sustainability of the fishery (Fuiman and Werner 2002). Managers could then easily decide to close a given area or season to fishing in order to protect spawning and nursery grounds, which would ultimately benefit the sustainability of the fishery.

Acknowledgements. This work was funded jointly by the Region Nord-Pas de Calais and Ifremer. We also acknowledge financial support from the EU as part of the ISADO and CHARM projects (ERDF - Interreg III and IVA France [Manche - Angleterre]). Thanks also to the crew of the RV 'Thalassa' for their support in sampling at sea. G.E.M. is a post-doctoral researcher funded by the Research Foundation-Flanders (FWO-Vlaanderen).

\section{LITERATURE CITED}

Akimoto S, Kinoshita S, Sezaki K, Mitami I (2002) Identification of alfonsino and related fish species belonging to the genus Beryx with mitochondrial 16S rRNA gene and its application on their pelagic eggs. Fish Sci 68:1242-1249

- Aoyama J, Ishikawa S, Otake T, Mochioka N and others (2001) Molecular approach to species identification of eggs with respect to determination of the spawning site of the Japanese eel Anguilla japonica. Fish Sci 67:761-763

> Aranishi F, Okimoto T, Ohkubo M, Izumi S (2005) Molecular identification of commercial spicy pollack roe products by PCR-RFLP analysis. J Food Sci 70:C235-C238

> Bayha KM, Graham WM, Hernandez FJ Jr (2008) Multiplex assay to identify eggs of three fish species from the northern Gulf of Mexico, using locked nucleic acid Taqman real-time PCR probes. Aquat Biol 4:65-73

Bellier E, Planque B, Petitgas P (2007) Historical fluctuations in spawning location of anchovy (Engraulis encrasicolus) and sardine (Sardina pilchardus) in the Bay of Biscay during 1967-73 and 2000-2004. Fish Oceanogr 16:1-15

Bohl H (1957) Die Biologie der Kliesche (Limanda limanda L.) in der Nordsee. Ber Dtsch Wiss Komm Meeresforsch 15:1-57

> Borja A, Uriarte A, Egana J, Motos L, Valencia V (1998) Relationships between anchovy (Engraulis encrasicolus) recruitment and environment in the Bay of Biscay (1967-1996). Fish Oceanogr 7:375-380

Borja A, Fontan A, Saenz J, Valencia V (2008) Climate, oceanography, and recruitment: the case of the Bay of Biscay anchovy (Engraulis encrasicolus). Fish Oceanogr 17:477-493

> Chakraborty A, Sakai M, Iwatsuki Y (2006) Museum fish specimens and molecular taxonomy: a comparative study on DNA extraction protocols and preservation techniques. J Appl Ichthyol 22:160-166

Chang YT, Loew GH (1994) Reaction mechanisms of formaldehyde with endocyclic imino groups of nucleic acid bases. J Am Chem Soc 116:3548-3555

Checkley DM Jr, Ortner PB, Settle LR, Cummings SR (1997) A continuous, underway fish egg sampler. Fish Oceanogr 6:58-73

Checkley DM Jr, Hunter JR, Motos L, van der Lingen CD (eds) (2000) Report of a workshop on the use of the Continuous Underway Fish Egg Sampler (CUFES) for mapping spawning habitats of pelagic fish, 9-11 February 2000, San Sebastián, Spain. GLOBEC Report 14, GLOBEC International Project Office, Plymouth

> Christensen A, Jensen H, Mosegaard H (2009) Spatially resolved fish population analysis for designing MPAs: influence on inside and neighbouring habitats. ICES J Mar Sci 66:56-63

Côté F, Finney J (2006) Marine protected areas: an essential element of the fisheries management toolbox. Bibliothèque du parlement, Ottawa

Daan N (1997) TAC management in North Sea flatfish fisheries. J Sea Res 37:321-341

Ehrenbaum E (1905-1909) Eier und Larven von Fischen des nordischen Planktons. Nord Plankton 1:1-413

Fisher J, Frank K (2002) Changes in finfish community structure associated with an offshore fishery closed area on the Scotian Shelf. Mar Ecol Prog Ser 240:249-264

- Fox C, Taylor I, Pereyra R, Villasana MI, Rico C (2005) TaqMan DNA technology confirms likely overestimation of cod (Gadus morhua L.) egg abundance in the Irish Sea: implication for the assessment of the cod stock and mapping of spawning areas using egg-based methods. Mol Ecol 14:879-884

> Fox CJ, Taylor M, Dickey-Collas M, Fossum P and others (2008) Mapping the spawning grounds of North Sea cod (Gadus morhua) by direct and indirect means. Proc R Soc Lond B Biol Sci 275:1543-1548

Fuiman LA, Werner RG (2002) Fishery science. The unique contribution of early life stages. Blackwell Publishing, Ames, IA

Gell FR, Roberts CM (2003) Benefits beyond boundaries: the fishery effects of marine reserves. Trends Ecol Evol 18: 448-455

Goodsir F, Armstrong MJ, Witthames PR, Maxwell DL, Fox CJ (2008) The use of species-specific TaqMan probes for identifying early stage gadoid eggs following formaldehyde fixation. ICES J Mar Sci 65:1573-1577

Greenstreet SPR, Spence FE, McMillan JA (1999) Fishing effects in northeast Atlantic shelf seas: patterns in fishing effort, diversity and community structure. V. Changes in structure of the North Sea groundfish species assemblage between 1925 and 1996. Fish Res 40: 153-183

Hall TA (1999) BioEdit: a user-friendly biological sequence alignment editor and analysis program for Windows 95/98/NT. Nucleic Acids Symp Ser 41:95-98 
Harding D, Nichols JH (1987) Plankton surveys off the north-east coast of England in 1976: an introductory report and summary of the results. Fish Res Tech Rep 86. Ministry of Agriculture, Fisheries and Food, Directorate of Fisheries Research, Lowestoft

Hawkins AD, Casaretto L, Picciulin M, Olsen K (2002) Locating spawning haddock by means of sound. Bioacoustics 12:284-286

Hedger R, McKenzie E, Heath M, Wright P, Scott B, Gallego A, Andrews J (2004) Analysis of the spatial distributions of mature cod (Gadus morhua) and haddock (Melanogrammus aeglefinus) abundance in the North Sea (1980-1999) using generalised additive models. Fish Res 70:17-25

Heessen H, Daan N, ter Hofstede R, Eastwood P and others (2005) ICES-FishMap, an online atlas of North Sea fish. Available at: www.ices.dk/marineworld/ices-fishmap.asp

$>$ Hilborn R, Stokes K, Maguire J, Smith T and others (2004) When can marine reserves improve fisheries management? Ocean Coast Manag 47:197-205

Hunter SE, Jung D, Di Giulio RT, Meyer JN (2010) The QPCR assay for analysis of mitochondrial DNA damage, repair, and relative copy number. Methods

Jennings S, Kaiser MJ, Reynolds JD (2001) Marine fisheries ecology. Blackwell Science, Oxford

> Jérôme M, Lemaire C, Bautista JM, Fleurence J, Etienne M (2003) Molecular phylogeny and species identification of sardines. J Agric Food Chem 51:43-50

Kalendar R, Lee D, Schulman AH (2009) FastPCR software for PCR primer and probe design and repeat search. Genes Genomes Genomics 3:1-14

Karaiskou N, Triantafyllidis A, Alvarez P, Lopes P, GarciaVazquez E, Triantaphyllidis C (2007) Horse mackerel egg identification using DNA methodology. Mar Ecol 28: 429-434

Kjærsgaard J, Vestergaard N, Kerstens K (2009) Ecological benchmarking to explore alternative fishing schemes to protect endangered species by substitution: the Danish demersal fishery in the North Sea. Environ Resour Econ 43:573-590

Kraus G, Pelletier D, Dubreuil J, Mollmann C and others (2009) A model-based evaluation of Marine Protected Areas: the example of eastern Baltic cod (Gadus morhua callarias L.). ICES J Mar Sci 66:109-121

Lelièvre S, Jérôme M, Vaz S, Verrez-Bagnis V (2010) Identification of formalin fish eggs in the Eastern Channel and Southern North Sea by molecular analyses. J Plankton Res 32:1527-1539

Lelièvre $\mathrm{S}, \mathrm{Vaz} \mathrm{S}$, Fox C (in press) The effectiveness of the Continuous Underway Fish Egg Sampler (CUFES) compared with standard vertical plankton haul for demersal species of southern North Sea. Fish Oceanogr

> Mello LGS, Rose GA (2005) Using geostatistics to quantify seasonal distribution and aggregation patterns of fishes: an example of Atlantic Cod (Gadus morhua). Can J Fish Aquat Sci 62:659-670

Munk P, Nielsen JG (eds) (2005) Eggs and larvae of North Sea fishes. Biofolia, Frederiksberg

Palmer ADN (2009) DNA isolation and amplification from formaldehyde-fixed animal tissues rich in mucopolysaccharides, pigments and chitin. Prep Biochem Biotechnol 39:72-80

Perez J, Alvarez P, Martinez JL, Garcia-Vazquez E (2005)

Editorial responsibility: Stylianos Somarakis,

Heraklion, Greece
Genetic identification of hake and megrim eggs in formaldehyde-fixed plankton samples. ICES J Mar Sci 62:908-914

Puyet A, Bautista J (2010) Detection of adulterations: identification of seafood species. In: Nollet L, Toldra F (eds) Handbook of seafood and seafood product analysis. CRC Press, Boca Raton, FL, p 687-712

Quéro JC, Vayne JJ (1997) Les poissons de mer des pêches françaises. Les encyclopédies du naturaliste. IFREMER. Editions Delachaux \& Niestlé, Paris

Rasmussen RS, Morrissey MT (2011) DNA-based detection of commercial fish species. In: Alasavar C, Shahidi F, Miyashita K, Wanasundara U (eds) Handbook of seafood quality, safety and health applications. Wiley-Blackwell, Malden, MA, p 290-302

Rijnsdorp AD, Vethaak AD, Van Leeuwen PI (1992) Population biology of dab Limanda limanda in the southeastern North Sea. Mar Ecol Prog Ser 91:19-35

Roberts CM, Hawkins JP, Gell FR (2005) The role of marine reserves in achieving sustainable fisheries. Philos Trans R Soc Lond B Biol Sci 360:123-132

Russell FS (1976) The egg and planktonic stages of British marine fishes. Academic Press, London

Sawada H, Saito H, Hosoi M, Toyohara H (2008) Evaluation of PCR methods for fixed bivalve larvae. J Mar Biol Assoc UK 88:1441-1449

Sezaki K, Kuboshima Y, Mitani I, Fukui A, Watabe S (2001) Identification of chub and spotted mackerels with mitochondrial cytochrome $b$ gene and its application to respective pelagic eggs fixed with formalin. Nippon Suisan Gakkai Shi 67:17-22

Širovi A, Cutter GR, Butler JL, Demer DA (2009) Rockfish sounds and their potential use for population monitoring in the Southern California Bight. ICES J Mar Sci 66: 981-990

Skage M, Schander C (2007) DNA from formalin-fixed tissue: extraction or repair? That is the question. Mar Biol Res 3:289-295

Taylor MI, Fox CJ, Rico I, Rico C (2002) Species-specific TaqMan probes for simultaneous identification of cod (Gadus morhua L.), haddock (Melanogrammus aeglefinus L.) and whiting (Merlangius merlangus L.). Mol Ecol Notes 2:599-601

Teletchea F (2009) Molecular identification methods of fish species: reassessment and possible applications. Rev Fish Biol Fish 19:265-293

Thompson BM, Riley JD (1981) Egg and larval development studies in the North Sea cod (Gadus morhua L.). Rapp P-V Reun Cons Int Explor Mer 17:553-559

> Van der Land M (1991) Distribution of flatfish eggs in the 1989 egg survey in the southeastern North Sea, and mortality of plaice and sole eggs. J Sea Res 27:277-286

Vaz S, Martin CS, Ernande B, Coppin F, Harrop S, Carpentier A (2005) Using geostatistics to quantify annual distribution and aggregation patterns of fishes in the eastern English Channel. Proc ICES Annu Sci Conf, 20-24 Sep 2005, Aberdeen. ICES CM 2005/L:21

Webster R, Oliver MA (2001) Geostatistics for environmental scientists. Wiley, Chichester

Zwolinski J, Mason E, Oliveira PB, Stratoudakis Y (2006) Fine-scale distribution of sardine (Sardina pilchardus) eggs and adults during a spawning event. J Sea Res 56: 294-304

Submitted: October 5, 2010; Accepted: October 10, 2011

Proofs received from author(s): January 16, 2012 